\title{
IS JAPAN THE "BRITAIN" OF EAST ASIA? A GEOPOLITICAL ANALYSIS OF JAPAN'S LONG-TERM STRATEGY ON THE KOREAN PENINSULA
}

\author{
Young-Hwan Shin ${ }^{1}$ \\ Korea University
}

\begin{abstract}
Japan's geographical location is often compared to that of the United Kingdom in Europe, and its strategic role is expected to correspond to Britain's as a balancer that has endeavored to keep the European world from being dominated by a hegemony or hegemonic coalition of powers. his geographical resemblance infers that Japan will play the role of a British balancer in East Asia. However, Japan differs from the UK geopolitically. If it were a balancer, Japan would welcome a more stable Korean Peninsula able to manage unexpected provocation from the North. Instead, Japan is skeptical about today's changing inter-Korean situation, following the Panmunjom Declaration on 27 April 2018. It needs to be understood that Japan has lain within a different geopolitical environment from Britain in Europe, which influenced different strategic choices in the history of East Asia.
\end{abstract}

Keywords: Japan, Korean Peninsula, geopolitics, balancer, insularity, seapower

Título en Castellano: ¿Es Japón la "Gran Bretaña" de Asia Oriental? Un análisis geopolítico de la estrategia a largo plazo de Japón en la Península de Corea

\section{Resumen}

La ubicación geográfica de Japón a menudo se compara con la del Reino Unido en Europa, y se espera que su papel estratégico corresponda a la de Gran Bretaña como una potencia equilibradora que se ha esforzado por evitar que el mundo europeo esté dominado por un poder hegemónico o una hegemónica coalición de poderes. Dada esta semejanza geográfica se deduce que Japón desempeñará el papel de un equilibrador británico en Asia oriental. Sin embargo, Japón difiere del Reino Unido geopolíticamente. Si fuera un equilibrador, Japón daría la bienvenida a una península coreana más estable capaz de gestionar las provocaciones inesperadas de Corea del Norte. En cambio, Japón es escéptico sobre la cambiante situación intercoreana actual tras la Declaración de Panmunjom del 27 de abril de 2018. Hay que entender que Japón se encuentra en un entorno geopolítico diferente de Gran Bretaña en Europa, lo que ha acabado influyendo en las diferentes opciones estratégicas en la historia de Asia Oriental.

Palabras Clave: Japón, Península de Corea, geopolítica, equilibrador, insularidad, poder marítimo.

Copyright () UNISCI, 2019.

Las opiniones expresadas en estos artículos son propias de sus autores, y no reflejan necesariamente la opinión de UNISCI. The views expressed in these articles are those of the authors, and do not necessarily reflect the views of UNISCI.

\footnotetext{
${ }^{1}$ Young-Hwan Shin is Research fellow at the Department of Political Science and International Relations, Korea University.

E-mail: <.yhshin@gmail.com>

DOI: http://dx.doi.org/10.31439/UNISCI-76
} 


\section{Introduction}

The inter-Korean summit in 2018, which adopted the Panmunjom Declaration for Peace, Prosperity and Reunification of the Korean Peninsula, was expected to mark a historical turning point on the Korean Peninsula. Thirty years have passed since and end was declared to the allout conflict of the Cold War at Malta, but the two Koreas on the Peninsula are still under the shadow of Cold War of twentieth century. There were several opportunities to better the devastated relationship between the two, including the first attempt to have an inter-Korean summit just after former U.S. president Jimmy Carter's reconciliation in 1994, and inter-Korean economic cooperation and the Sunshine Policy under the Kim Dae-jung administration in early 2000s, but unfortunately all of these efforts were frustrated. After the collapse of the socialist bloc, North Korea faced a serious security threat and was not able to guarantee its survival as an independent sovereign. The isolated North chose to defend itself by taking the security of its neighbors and the world hostage through developing of weapons of mass destruction, including nuclear weapons. North Korea's nuclear program has always been the steepest obstacle aggravating the insecurity on the Korean Peninsula. At the end of the long thread of failed efforts, the Panmunjom Declaration provided a foundation upon which to promote peace on the Korean Peninsula through denuclearization, mutual trust, and cooperation.

Since the inter-Korean summit in April 2018, the situation on the Korean Peninsula has not been a smooth path toward peace building; rather, it has been a series of both ambitious leaps forward and discouraging steps backward. But the game is not over, and players are moving on the ground. The inter-Korean relationship is mainly a matter of the two Koreas themselves, but their efforts to build peace need support from neighboring countries, as security on the Korean Peninsula may influence regional stability in East Asia and beyond. The peace process is like following stepping-stones made of fragile glass, demanding delicate deliberation and cautious moves from the players involved. The South Korean government has been cooperating with the U.S., who is mainly a stakeholder in the nuclear issue, and coordinating policy options as an alliance. Meanwhile, Kim Jong Un visited Xi Jinping at a critical moment ahead of the first U.S.-North Korea summit at Hanoi.

At the Panmunjom Summit, Japan officially acknowledged the South Korean government's effort to promote peace on the Korean Peninsula. Japanese Chief Cabinet Secretary Yoshihide Suga also indicated the shared interest among U.S., Japan, and South Korea regarding North Korea's missile threat. Since the Panmunjom Summit, Japan's role in the progress has been limited. Japan wanted to take advantage of the reconciliation process in order to address its security issues, including North Korea's missile threat and the abduction problem. Although the Japanese tried to arrange a summit with North Korea, they could not find any space on the vacillating ground, nor make room for their own agenda. Short and midrange missiles and abductions were not a main concern for Trump, and Moon did not want to add another player to the board in fear of making the already fragile process more complicated. Meanwhile, the Japanese government faced domestic criticism on Japan's minor role, with some even accusing them of passing.

While the cooperative process on the neighboring Peninsula was underway, the Japanese government did not show cooperative support for their South Korean counterparts. Though they welcomed the cooperative effort to denuclearize, they continually attempted to add Japanese agenda items such as short and mid-range missiles and Japanese abductions as preconditions for further negotiation. Just after the collapse of Hanoi Summit, Prime Minister Shinzo Abe made a phone call to President Trump and said that he respected Trump's decision not to negotiate with Kim Jong Un on his request for sanctions relief. Japan wanted to continue the UN sanction regime against North Korea, which has been the constant position of Tokyo 
toward Pyongyang. ${ }^{2}$ In addition, the South Korea-Japan relationship has sharply deteriorated, mainly due to the South Korean government's decision to reinvestigate the "Comfort Women" agreement and the ruling of the Supreme Court of South Korea in favor of compensation for the illegally mobilized Korean laborers. In the current state, it will be difficult to expect Tokyo to have a supportive attitude toward Seoul's efforts to negotiate with Pyongyang. It seems that Seoul is also not anticipating assistance from its neighboring islands.

"So close, yet so far" ${ }^{3}$ describes the South Korea-Japan relationship very well. Geographically the two nations are close, but their interests and perspectives contradict each other in many respects. Japan's strategic attitude toward the Korean Peninsula seems to be different from what South Korea formulates. Though South Korea and Japan are respectively allied with U.S. based on common security interests, security cooperation between the two remains limited. What accounts for this divergence? Historical issues between the two countries underlie the discord, but is not the only factor. South Korea and Japan have their own interests and strategic evaluation with regard to their different circumstances. Therefore, this article would like to shine a light on the geopolitical framework, which understands a nation's foreign policies and actions in view of its geographical location, regional position, and arrangement among neighboring countries. Geography is a constant and stable factor which influences people's lives and is where geopolitics begin. It argues that the spatial position of a country should be considered in order to understand a nation's foreign policies and actions directed by national interest and strategic calculation, which are defined by political efforts to utilize advantages and overcome disadvantages given by natural space of life. ${ }^{4}$ Geopolitics can foster understanding of long-term trends that govern state actions and perspectives. If we understand Japan's geopolitically defined perspectives and interests regarding the Korean Peninsula, we may be able to understand why Japan's role in supporting the reconciliatory effort between the two Koreas would be limited.

\section{Insularity Reconsidered}

When we discuss British history and its foreign affairs, especially its relations with the European continent, its geographical condition as an island facing the continent is often considered first. As described in the speech delivered by dying John of Gaunt in Shakespeare's play Richard II, the isle is respected as beautiful, majestic, and blessed, who is given the "fortress built by nature for herself, against infection and the hand of war." Insularity "bound in with the triumphant sea"5 has set the UK's policy options with regard to outside world, and it defined itself as a balancer, who sought a balance of power on the continent. ${ }^{6}$ A hegemon on the continent which succeeded in extending its power to the farthest frontier on the shore would then threaten the island across the sea.

Japan, which is insular on the opposite side of the globe, is often compared to the UK due to its similar geographical situation. Historically, Japan has enjoyed security provided by the triumphant sea, which separated it from continental threats, until the failed invasions by the Mongolians in the thirteenth century. After submitting Korea to its vassaldom, Mongolia

\footnotetext{
${ }^{2}$ Smith, Sheila A.: "The Hanoi Setback and Tokyo's North Korea Problem," Council on Foreign Relations (2019), at https://www.cfr.org/blog/hanoi-setback-and-tokyos-north-korea-problem.

3 Glosserman, Brad: "Japan-South Korea: So Close, yet So Far," The Diplomat (2018), at https://thediplomat.com/2018/02/japan-south-korea-so-close-yet-so-far/.

${ }^{4}$ For the influence of geographical conditions on national interests and foreign policy, see, Kelly, Phil (2016): Classical Geopolitics: A New Analytical Model, Stanford University Press, pp.1-17.

${ }^{5}$ Quotations are from William Shakespeare's Richard II, Act 2, Scene 1. Shakespeare, William: "The Complete Works of William Shakespeare," at http://shakespeare.mit.edu/richardii/richardii.2.1.html.

${ }^{6}$ For the history of the British role of balancing on continental Europe, see, Simms, Brendan (2017): Britain's Europe: A Thousand Years of Conflict and Cooperation, London, Penguin Books.
} 
attempted to invade Japan, but both Mongolian campaigns were frustrated by an invincible natural force, namely the kamikaze or "divine wind." 7 Other than extreme Mongolian expansionism, Japan never faced a serious war threat from the Asian landmass until the nineteenth century. Insularity provided Japan with the same advantageous security conditions enjoyed by the UK.

However, the power arrangements in Asia did not give Japan an opportunity to play the role of a balancer toward the Asian continent. Traditionally, the Asian region was under a hierarchical order wherein China was the sole great power that ruled through Sino-centrism, until the western imperialism entered the picture. Chinese hegemony presided over the Asian region both physically and ideologically for more than a thousand years, where "peripheral" countries were dependent upon the hierarchy for their security and development. The Chinese tributary system, ${ }^{8}$ which is considered to have been established during the Tang Dynasty, was based on a Confucian image of world order where peripheral obeisance was exchanged for the mercy of the ruler of China. ${ }^{9}$ However, Japan stayed one step away from the Chinese tributary system, which made them more autonomous and less Confucian, and Japan's insular position was a bulwark which mitigated the pressure from the Chinese hegemony.

When European imperialist expansion came to East Asia in the nineteenth century, Japan changed its strategic position of insular isolation. The UK, as a balancer toward the European continent, extended its role to the Far East, where she wanted to be able to check and defeat other competitors on the ground, especially Russia's southward expansion. Therefore, the UK expected that Japan would contribute to deterring Russian expansion by playing the role of a balancer, as she had done in the West. The Japanese, who were unsatisfied despite winning the war with China, were also concerned about Russian expansionism. This common interest finally resulted in the Anglo-Japanese Alliance in 1902, which was revised and extended in scope twice later on. ${ }^{10}$ China was rapidly declining, western powers were competing to fill the power vacuum left behind by the Qing dynasty, and Japan chose to participate in the struggle as the only Asian power. Instead of being a balancer toward the Asian continent, imperial Japan strived to expand its influence in order to build the "Greater East Asia Co-Prosperity Sphere."

During the Cold War period, Japan was allied with the U.S., who tried to deter socialist expansion and its threat to the liberal world. The U.S., partnered mainly with the UK, built the collective security mechanism to deter the Soviet threat on the western side of the World Island, ${ }^{11}$ and it allied with Japan and South Korea on the eastern end for the same purpose. After the end of the Cold War, Francis Fukuyama judged the triumph of liberal democracy by declaring the "End of History," 12 but the liberal leadership of U.S. failed to overcome the "Tragedy of the Great Power Politics."13 Under the unipolar world led by the U.S., today's peculiar changes can be characterized by rising China, which has endeavored to return as great

\footnotetext{
${ }^{7}$ Neumann, J.: "Great Historical Events That Were Significantly Affected by the Weather: I. The Mongol Invasions of Japan", Bulletin of the American Meteorological Society, Vol. 56, no 11 (1975).

${ }^{8}$ The concept of the "tribute system" was first invented by a western historian, John King Fairbank. See, Fairbank, John King (ed.) (1968): The Chinese World Order: Traditional China's Foreign Relations, Cambridge, Harvard University Press.

${ }^{9}$ Lee, Ji-Young (2016): China's Hegemony: Four Hundred Years of East Asian Domination, New York, Columbia University Press.

${ }^{10}$ Steiner, Zara S.: "Great Britain and the Creation of the Anglo-Japanese Alliance", The Journal of Modern History, Vol. 31, $\mathrm{n}^{\circ} 1$ (1959).

${ }^{11}$ For concept of the "World Island," see Mackinder, Halford J.: "The Geographical Pivot of History", The Geographical Journal Vol. 23, no 4 (1904).

${ }^{12}$ Fukuyama, Francis: "The End of History?", The National Interest, no 16 (1989).

${ }^{13}$ Mearsheimer, John J. (2001): The Tragedy of Great Power Politics, New York, W.W. Norton \& Company.
} 
power on the Asian landmass with rapid economic growth since Deng Xiaoping's economic reforms. Again, Japan is facing pressure from the great landpower of China today, which means that Japan cannot be a balancer in East Asia, rather sharing interest with U.S. under the alliance system to deter the threat from the continent.

Historically, foreign affairs on the Asian continent were far different from Europe, and Asian countries did not conceive of the concept of balance of power until the only great power, China, declined with the introduction of power politics from the West. Under the traditional Chinese hegemony, Japan was required to comply with the benign Confucian hierarchy enjoying relative autonomy given by its insularity. With the decline of China and the rise of imperial competition, Japan chose to join the imperial competition. Today, Japan is once again facing a rising China, which has overtaken Japan in GDP volume since 2010 and redistributed its wealth to modernize its military capabilities. The geopolitical landscape in East Asia does not encourage insular Japan to be a balancer.

\section{The Geopolitical Position of Korean Peninsula}

Under the traditional Chinese tributary system, Korea sought the Chinese emperor's endorsement of its faithfulness in complying with Confucian ideology and Sino-centrism. Considering Korea's geographical position located on the northeastern periphery of China's terrain protruding southward as a Peninsula, most of the security threats came mainly from the north, where minor ethnic tribes struggled against one another. Therefore, it was essential for Korean security to have good relationship with a strong China capable of stabilizing the northeastern region which would counter any threats from the north. By complying with the Chinese Confucian hierarchy, Korea was able to protect itself from external threats and also strengthen and legitimize the authority of the regime internally.

The geopolitical position of Korean Peninsula was first recognized in 1592, when Japan attacked Korea across the sea after completing irredentism on the islands. Toyotomi Hideyoshi, the most powerful military leader in Japan who initiated the Imjin War, had an ambition to expand his rule over not only insular Japan but also the Asian mainland. He officially requested that Korea guide the way to invade China, and initiated the war by dispatching fleets of 7,000 troops to Busan. ${ }^{14}$ During the Imjin War, Korea was placed in the position between the traditional sole great power, China, and the rising Japan. Korea was perceived as a "bridgehead" by Japan for projecting its power toward mainland Asia, and also regarded as a "buffer zone" by China for deterring Japanese expansion out of China's territory. With end of the war, the Chinese tributary system was restored under the Qing Dynasty, but Korea's geopolitical tragedy resumed in the turbulence of great power rivalry in the late nineteenth century. During the Meiji period, Japan referenced the failed ambition of Toyotomi Hideyoshi, arguing for Seikanron (advocacy for subduing Korea), which was not adopted but rather delayed. ${ }^{15}$ Japan, as a rising power in Asia, once again considered the Korean Peninsula as a bridgehead which was necessary to build an outpost for expansion to Asian continent, and finally annexed Korea to extend its sphere of influence. Therefore, imperialist Japan established the advance base on the

\footnotetext{
${ }^{14}$ For a discussion of the Imjin War with geographical and technological analysis, see Jacob, Frank: "Technological Spatialities: The Impact of Geography and Technology During the Imjin War (1592-1598)," in Danielsson, Sarah K. and Jacob, Frank (eds.) (2017): War and Geography: The Spatiality of Organized Mass Violence, Ferdinand Schöningh, pp.25-38.

${ }^{15}$ For Japan's policy consideration on subduing Korea, see Duus, Peter (1995): The Abacus and the Sword: The Japanese Penetration of Korea, 1895-1910, Berkeley, University of California Press, pp.31-43.
} 
Korean Peninsula toward the "World Island" out of the "outer crescent" the "Greater East Asia Co-Prosperity Sphere."17

However, Japan's geopolitical policy was not based on its unique geographical condition as an insular state facing and circumscribing the Asian continent. In the 1920s, the continental theory of Geopolitik developed in Germany was first introduced to Japan, which understood state policy and actions through organic analogy ${ }^{18}$ and emphasized the importance of Lebensraum, which aims to achieve autarky and consequently justifies the expansion of panregions for the development and prosperity of a state. Japanese geographers were not interested in the new theory, which combined politics and geography, until the 1930s. From the late 1930s onward, geopolitics became increasingly attractive to intellectuals and statesmen and was finally adopted by militaristic policy makers to justify its expansionism. ${ }^{19}$ Japan did not identify itself as a seapower whose security concern was mainly concentrated on countering hegemony on the continent; rather, it mobilized naval power to attain Lebensraum and autarky and build its leadership in "Greater East Asia."

Small states which are "in between" greater ones are often regarded as geopolitical "buffer zones," which mitigate the pressures of great powers from either side and consequently stabilize the region by keeping rival powers from warring against each other. However, buffer states often suffer consequences as external pressures nibble away at the buffer's own pie. Sometimes buffer states are forced to make diplomatic concessions due to outside pressure, and even provide the battleground for wars, giving conquered lands over to their larger competitors. ${ }^{20}$ Therefore, small buffer states are usually vulnerable to pressure from neighboring larger states, and are weakened to the point of being unable to survive as independent sovereigns. ${ }^{21}$ This theoretical explanation fits well with Korea's history. Korea was neither able to mitigate external pressures nor to protect itself from imperialist competition in East Asia in the nineteenth century. Internal politics disintegrated, and each faction strived for assistance from outside great powers in order to win its own privilege, which accelerated down to "shatterbelt." Finally, it had to surrender its sovereignty to Japanese colonialism.

Even after liberation from Japanese colonialism, Korea's geopolitical situation was unfavorable for establishing its own sovereignty. Unfortunately, as internal political struggle erupted and once again drew external intervention from competing great powers Korean Peninsula rapidly became a "shatterbelt." Shatterbelts play the role of destabilizing regions as escalating internal competition combines with external intervention, sometimes to the point of

\footnotetext{
${ }^{16}$ Mackinder categorized the Japanese islands to the outer crescent. Mackinder, op.cit. pp.434-436.

${ }^{17}$ Militaristic expansionism can be also found in primary school geography textbooks from those days. The geographical location and shape of the Japanese islands was interpreted to mean Japan is in the center of greater East Asia and it "appeared to stand in front of the Asian continent and go forward to the Pacific Ocean bravely." Takagi, Akihiko: "Japanese Nationalism and Geographical Thought", Geopolitics Vol. 3, n 3 (1998), pp.129-132. ${ }^{18}$ A Swedish political scientist, Rudolf Kjellén, presented the concept of geopolitik first in order to explain a state's behavior regarding its territory with organic state theory, which was based in the concept of social Darwinism. His idea was welcomed in Germany and provided a theoretical framework for developing the German Geopolitik, which was adopted by the National Socialists. Holdar, Sven: "The Ideal State and the Power of Geography the Life-Work of Rudolf Kjellén," Political Geography Vol. 11, no 3 (1992); Tunander, Ola: "Swedish-German Geopolitics for a New Century: Rudolf Kjellén's 'the State as a Living Organism', "Review of international Studies Vol. 27, no 3 (2001).

${ }^{19}$ Takeuchi, Keiichi: "Geopolitics and Geography in Japan Reexamined", Hitotsubashi Journal of Social Studies Vol. 12, no 1 (November 1980): Fukushima, Yoriko: "Japanese Geopolitics and Its Background: What Is the Real Legacy of the Past?," Political Geography Vol. 16, nº 5 (1997), pp.408-413.

${ }^{20}$ Kelly, op.cit., p.111.

${ }^{21}$ Fazal, Tanisha M.: "State Death in the International System," International Organization Vol. 58, no 2 (2004).
} 
war. ${ }^{22}$ Having become a shatterbelt after liberation, Koreans could not help but accept their division, with the south influenced by the U.S. and the north by the Soviet Union. The division of the nation further stimulated an ardent desire for irredentism on the Peninsula, and struggle and rivalry to become the only legitimate sovereign nation fueled the flames of war. The Korean War is a prime example of how shatterbelts bring about disaster. More than four million people were killed in the war, at least half of whom were civilians who suffered from massacres, indiscriminate bombing, starvation, disease, and other calamites. ${ }^{23}$ All of the major cities and industrial facilities on the Peninsula were terribly destroyed. The Korean War, ideological confrontation between liberals and socialists, was followed by systemization of full-scale global competition between the U.S. and the Soviet Union, which we know as the Cold War.

With the Korean War, the U.S. reevaluated the strategic value of the Korean Peninsula and embraced South Korea in its sphere of influence through the alliance system. The Cold War is described as total competition between the U.S. and the Soviet Union, which focused on military buildup, especially of nuclear weapons, as George Orwell warned that a "cold war" would cost an indefinite period of "a peace that is no peace" after witnessing atomic bombs dropping over Hiroshima and Nagasaki. ${ }^{24}$ The half century's confrontation may also be described in the framework of geopolitics, with the U.S. containment policy of securing rimlands ${ }^{25}$ to deter expansionist pressure from the Heartland which was mainly occupied by the Soviet Union and the socialist bloc. According to Nicholas Spykman's theory, the Korean Peninsula and Japan could be categorized into the rimland surrounding a huge landpower, and they were included in the U.S. alliance system. Under the U.S. alliance system, the rimlands of South Korea and Japan were considered the bulwark to contain socialist expansion from the east of landmass. The balance of power on the World Island did not function, as no state or coalition of states could effectively counter the expansion of the Soviet Union. Therefore, the insular U.S. had to intervene in continental affairs as a deterrer, not a balancer.

\section{A Junior Seapower in East Asia}

The geostrategic position of the Korean Peninsula cannot be evaluated and understood solely through maps. Through analyses on geographical location, relative position, territorial size and shape, arrangement, and configuration of power, the Korean Peninsula is interpreted as a buffer zone, a bridgehead, a shatterbelt, a bulwark, or some combination of each. We may estimate which best describes the region by analyzing the interests and policies of great powers surrounding the Peninsula, as geopolitics bar Koreans from deciding their own destiny. Therefore, it is necessary to look at today's power configuration and assess the competing interests of major actors in the region together with the framework of geopolitics which is helpful for assessing long-term tendency of international relations.

In autumn of 1995, Jiang Zemin declared that China would be both landpower and seapower and emphasized the increasing importance of naval capacity for the future development of the country. He also argued that China should modernize its naval power to

\footnotetext{
${ }^{22}$ For more on the concept of shatterbelts, see Cohen, Saul Bernard (2015): Geopolitics: The Geography of International Relations, Maryland, Rowman \& Littlefield, pp.48-49.

${ }^{23}$ Cumings, Bruce (2010): The Korean War: A History, New York, Modern Library, pp.35-36.

${ }^{24}$ Orwell, George: "You and the Atomic Bomb", Tribune, 19 October 1945.

${ }^{25}$ Nicholas J. Spykman's rimland theory can be interpreted as an American version of Mackinder's Heartland thesis. He emphasized the importance of control of rimland lest the U.S. should be faced with threats from hegemonic landpower on the continent, which provided the theoretical basis for the containment policy against the Soviet Union during the Cold War era. For the rimland theory, see The Geography of the Peace, New York, Harcourt, Brace and Company; Spykman, Nicholas J. (1942): America's Strategy in World Politics: The United States and the Balance of Power, New York, Harcourt, Brace and Co..
} 
address coming challenges ${ }^{26}$ Recently, China manifested its vital interests in the East and South China Seas, evoking tensions among neighboring countries. Although the Permanent Court of Arbitration (PCA) did not endorse China's request for historical rights over the sea, China has rejected the PCA's ruling. Traditionally, China has been regarded as a landpower located on the Asian continent, and its ground forces have been at the center of guarding its security interests. However, with the end of Cold War and the new world order of U.S. unipolarity, China's strategic calculation changed to pursue the Mahanian maxim, ${ }^{27}$ advocating for a multipolar world based on harmonious great power relations. The navy buildup of a landpower brings to mind the German experience after Bismarck, which challenged the status quo in European ground. ${ }^{28}$

The U.S. revived geopolitics, which were dormant for a few short years after the end of the Cold War. The U.S. alliances in the Atlantic and Asia-Pacific regions could not be abrogated, and Barack Obama declared a significant shift in U.S. foreign policy through his "pivot to Asia," which later transformed to "rebalancing." This reaffirms Brzezinski's assertion that the top priority of U.S. foreign policy should be preventing any power from rising to hegemony on the Eurasian continent which could challenge American vital interests across the oceans. ${ }^{29}$ Another shift in U.S. foreign policy also needs our attention. As Frank Klingberg suggested more than 60 years ago,${ }^{30}$ today's American foreign policy seems to be on the way back to "introversion." Donald Trump's slogan of "America First" represents not only his personal preference, but increasing pressure coming from domestic fatigue over the country's long-term, burdensome internationalism. Considering Klingberg's cycle theory, the introversion trend will not be temporary, but it won't be possible for U.S. to fully return to "splendid isolation," because we have seen the U.S. in a stabilizing role through historical experiences in the two great wars and "the long peace." 31 Therefore, the U.S. is trying to reduce its own burden in maintaining the alliance system by requesting that its allies pay more while also transforming its role to one of offshore balancing.

Under this changing strategic environment, Japan is seeking a new role in East Asia that breaks free of its postwar limitations. The introversion of the U.S. requires that Japan take a more active role in the Western Pacific, and Japan is willing to take advantage of this moment to escape the shackles of the "Peace Constitution," which limits Japan's right to wage war. The U.S. "buck-passing" to allies gives Japan not only burden, but also opportunity to once again become a "normal country." 32 Abe Shinzo is keeping a close watch for the optimal time to revise the Constitution, and this has given rise to concerns and criticism among neighboring countries who were victims of Japanese imperialism in the past. However, U.S. will not put

\footnotetext{
${ }^{26}$ Cole, Bernard D. (2010): The Great Wall at Sea: China's Navy in the Twenty-First Century, Annapolis, Maryland, Naval Institute Press, p.179.

${ }^{27}$ For the essential role of sea power in history, see Mahan, Alfred Thayer (1890): The Influence of Sea Power Upon History, 1660-1783, Boston, Little, Brown and Company.

${ }^{28}$ Kang, Sung-Hack (2017): Korean Geopolitics and Lincoln's Leadership: East Asian Geopolitical Change and the Leadership for National Unification (in Korean), Seoul, Korea University Press, pp.47-54.

${ }^{29}$ Brzezinski, Zbigniew (1997): The Grand Chessboard: American Primacy and Its Geostrategic Imperatives, New York, Basic Books, xiv.

${ }^{30}$ Klingberg argued that American foreign policy trend swings between introversion and extroversion by 20 years' cycle. Klingberg, Frank L.: "The Historical Alternation of Moods in American Foreign Policy", World Politics, Vol. 4, n⿳2 2 (1952).

${ }^{31}$ Gaddis, John Lewis: "The Long Peace: Elements of Stability in the Postwar International System", International Security, Vol. 10, No. 4 (1986). Also, for discussion on America's role as a global stabilizer today and the near future, see, Brzezinski, Zbigniew (2012): Strategic Vision: America and the Crisis of Global Power, New York: Basic Books, pp.75-120.

32 Lionel Pierre Fatton, "Is Japan Now Finally a Normal Country?", The Diplomat (2013), at https://thediplomat.com/2013/12/is-japan-now-finally-a-normal-country/.
} 
aside its vital interests in the Asia-Pacific and Japan's role will be managed under U.S. initiative, as long as there are no other candidates to take over the superior American role. Therefore, it may stand to reason that in principle, Japan understands the strategic position of Korean Peninsula in the same way that the U.S. does.

However, Japan has some different perceptions from the U.S. that originate from its geographical position. First, because of its proximity to the continent, Japan may face an immediate threat from the Asian mainland, where China is rising. So, the Korean Peninsula is expected to be a bulwark or a buffer which can mitigate the continental pressure better than the U.S. Second, Japan sees two frontiers against continental pressure on the Korean Peninsula, one of which is drawn between the two Koreas and the other which advances farther to the border between North Korea and China. Although North Korea is a real threat to Japanese security, it provides a barrier which ironically neutralizes influence from the continent. Third, Japan has territorial issues with its neighboring countries, including Dokdo with South Korea, the Kuril Islands with Russia, and the Senkaku Islands with China. Considering that the other three countries have resolved the territorial conflicts among them, Japan is perceived as being relatively more insecure in the region. Thus, Japan hopes that South Korea will bind itself concretely to the U.S. alliance system, and occasionally fears that South Korea may move closer to China, questioning South Korea's pro-China shift. Fourth, Japan conceives of a more autonomous role for itself in the future as a junior partner of the greater seapower of the U.S. Japan seems to define the Korean Peninsula as a bridgehead from its own perspective rather than as a surrogate of the U.S. This perspective is based on the asymmetric relationship between South Korea and Japan rather than security partners.

However, Koreans do not wish to repeat past historical tragedies, and seem to hope that they can overcome the geopolitical trap. Instead of being a doomed buffer zone or a bridgehead dependent on greater seapower, Korea may wish to become a geopolitical "lintel state" or "gateway." Lintel states resemble a buffer with regard to their geographical arrangement, meaning they are small states surrounded by great powers. But lintel states have sufficient capacity to address external pressure and can manage regional competition as balancers. Gateway states play the role of regional stabilizers, linking different parts of the region by promoting the exchange of people, goods, and ideas. ${ }^{33}$ However, it should be mentioned that a small power's strategic position is not determined by its own effort. Rather, a smaller state's capacity to become a lintel or a gateway depends on compromise among the surrounding greater powers. Both aspirational designations require neutrality as a precondition, and the neutrality of small states is a byproduct of the balance of power, compromise, or recognition among great powers. ${ }^{34}$ Therefore, the potential alternatives for Korean Peninsula seem neither possible nor desirable, given that the alliance with the U.S. is vital for South Korea's security with the shifting geopolitical configuration in East Asia.

The Korean aspiration for unification and U.S. willingness to control the nuclear threat from the North have converged to preserve the efforts to ease tensions on the Korean Peninsula. Denuclearization and the peace process on the Korean Peninsula will contribute to stability in East Asian region, which may be welcomed by Japan as well. However, the reality is not so simple when we consider geopolitical positions and the different interests of each player in the region. In addition, history issues have seriously derogated the bilateral relationship between

\footnotetext{
${ }^{33}$ Cohen, op.cit., pp.54-55.

${ }^{34}$ Morgenthau, Hans J.: "The Resurrection of Neutrality in Europe," American Political Science Review, Vol. 33, no 3 (1939), pp.482-483; Morgenthau, Hans J. (1985): Politics among Nations: The Struggle for Power and Peace, 6th ed., New York, Alfred A. Knopf Inc., p.196.
} 
South Korea and Japan today, and continue to be an obstacle to mutual cooperation under the U.S. alliance.

\section{Conclusion}

The geopolitical framework provides a clearer picture to understand the different interests and perspectives of states in East Asia. The traditional theory of realism in international relations is not adequate to understand the complex and dynamic aspects of what is going on in the region. However, if we examine the geopolitical configuration including geographical location, relative position, and arrangement, then Japan's path in history becomes clear. Although Japan's geopolitical situation did not allow to be a balancer in East Asia as the UK has in Europe, it could be a deterrer to counter a rising hegemony on the Asian mainland. Rather, it eventually sought expansionism, which resulted in war. Japan and the UK share the characteristic of geographical insularity, but the regional geopolitical configuration where each is located differ sharply. Thus, the UK was a stabilizer, but Japan was a challenger. In the postwar period, Japan has had to become the junior partner of a greater deterrer.

Japan's strategic evaluation and attitude toward the Korean Peninsula can be summarized as one of asymmetry, as the Japanese see the Peninsula as a bridgehead to counter pressures from the Asian continent. South Korea's trauma hangover from the geopolitical tragedies it has suffered in the past makes it difficult to accept the Japanese perspective. This divergence has resulted in the deteriorated relationship of today, which has in turn hampered cooperative efforts for a peace process on the Korean Peninsula and ultimately in East Asia. However, understanding the divergence also provides the opportunity for mutual understanding and recognition of common interests for regional security. Considering the current geopolitical configuration in East Asia, it is not an exaggeration to say that cooperation between South Korea and Japan is required to ease the situation on the Korean Peninsula and ensure stability in East Asia.

\section{Bibliography}

Brzezinski, Zbigniew (1997): The Grand Chessboard: American Primacy and Its Geostrategic Imperatives, New York, Basic Books.

Books.

(2012): Strategic Vision: America and the Crisis of Global Power, New York, Basic

Cohen, Saul Bernard (2015): Geopolitics: The Geography of International Relations, Maryland, Rowman \& Littlefield.

Cole, Bernard D. (2010): The Great Wall at Sea: China's Navy in the Twenty-First Century, Annapolis, Maryland, Naval Institute Press.

Cumings, Bruce (2010): The Korean War: A History, New York, Modern Library.

Duus, Peter (1995): The Abacus and the Sword: The Japanese Penetration of Korea, 18951910, Berkeley: University of California Press.

Fairbank, John King (ed.) (1968): The Chinese World Order: Traditional China's Foreign Relations, Cambridge, Harvard University Press.

Fatton, Lionel Pierre: "Is Japan Now Finally a Normal Country?", The Diplomat (2013), at https://thediplomat.com/2013/12/is-japan-now-finally-a-normal-country/. 
Fazal, Tanisha M: "State Death in the International System", International Organization, Vol. 58, nº 2 (2004), pp.311-344.

Fukushima, Yoriko: "Japanese Geopolitics and Its Background: What Is the Real Legacy of the Past?", Political Geography, Vol. 16, no 5 (1997), pp.407-421.

Fukuyama, Francis: "The End of History?", The National Interest, nº 16 (1989), pp.3-18.

Gaddis, John Lewis: "The Long Peace: Elements of Stability in the Postwar International System", International Security, Vol. 10, nº 4 (1986), pp.99-142.

Glosserman, Brad: "Japan-South Korea: So Close, yet So Far", The Diplomat (2018), at https://thediplomat.com/2018/02/japan-south-korea-so-close-yet-so-far/.

Holdar, Sven: "The Ideal State and the Power of Geography the Life-Work of Rudolf Kjellén", Political Geography, Vol. 11, nº 3 (1992), pp.307-323.

Jacob, Frank: "Technological Spatialities: The Impact of Geography and Technology During the Imjin War (1592-1598)", in Danielsson, Sarah K. and Jacob, Frank (eds.) (2017): War and Geography: The Spatiality of Organized Mass Violence, Ferdinand Schöningh.

Kang, Sung-Hack (2017): Korean Geopolitics and Lincoln's Leadership: East Asian Geopolitical Change and the Leadership for National Unification (in Korean), Seoul, Korea University Press,.

Kelly, Phil (2016): Classical Geopolitics: A New Analytical Model, Stanford University Press.

Klingberg, Frank L.: "The Historical Alternation of Moods in American Foreign Policy", World Politics, Vol. 4, nº 2 (1952), pp.239-273.

Lee, Ji-Young (2016): China's Hegemony: Four Hundred Years of East Asian Domination, New York, Columbia University Press.

Mackinder, Halford J.: "The Geographical Pivot of History", The Geographical Journal, Vol. 23, no 4 (1904), pp.421-437.

Mahan, Alfred Thayer (1890): The Influence of Sea Power Upon History, 1660-1783, Boston, Little, Brown and Company.

Mearsheimer, John J. (2001): The Tragedy of Great Power Politics, New York, W.W. Norton \& Company

Morgenthau, Hans J.: "The Resurrection of Neutrality in Europe", American Political Science Review, Vol. 33, nº 3 (1939), pp.473-86.

(1985): Politics among Nations: The Struggle for Power and Peace, 6th ed., New York, Alfred A. Knopf Inc.

Neumann, J.: "Great Historical Events That Were Significantly Affected by the Weather: I. The Mongol Invasions of Japan", Bulletin of the American Meteorological Society, Vol. 56, $\mathrm{n}^{\mathrm{o}} 11$ (1975), pp.1167-1171.

Orwell, George: "You and the Atomic Bomb", Tribune, 19 October 1945.

Shakespeare, William: "The Complete Works of William Shakespeare", at http://shakespeare.mit.edu/richardii/richardii.2.1.html.

Simms, Brendan (2017): Britain's Europe: A Thousand Years of Conflict and Cooperation, London, Penguin Books.

Smith, Sheila A. "The Hanoi Setback and Tokyo's North Korea Problem", Council on Foreign Relations (2019), at https://www.cfr.org/blog/hanoi-setback-and-tokyos-north-korea-problem. 
Spykman, Nicholas J. (1942): America's Strategy in World Politics: The United States and the Balance of Power, New York, Harcourt, Brace and Co.

(1944): The Geography of the Peace, New York, Harcourt, Brace and Company.

Steiner, Zara S.: "Great Britain and the Creation of the Anglo-Japanese Alliance", The Journal of Modern History, Vol. 31, no 1 (1959), pp.27-36.

Takagi, Akihiko: "Japanese Nationalism and Geographical Thought", Geopolitics, Vol. 3, no 3 (1998), pp.125-139.

Tunander, Ola: "Swedish-German Geopolitics for a New Century: Rudolf Kjellén's 'the State as a Living Organism'", Review of International Studies, Vol. 27, n 3 (2001), pp.451-463. 